\title{
CrimRxiv
}

\section{Decarcerating Correctional Facilities during COVID-19: Advancing Health, Equity, and Safety}

National Research Council

Published on: Mar 07, 2022

DOI: $10.21428 / \mathrm{cb} 6 a b 371.19 a 1 d 8 f 2$

License: Creative Commons Attribution 4.0 International License (CC-BY 4.0). 
